ISSN No. 0974-035X

An indexed refereed \& peer-reviewed journal of higher education

Towards Excellence

UGC-HUMAN RESOURCE DEVELOPMENT CENTRE

Gujarat University, Ahmedabad-380009, Gujarat, India

\title{
BUCHANS: A MINING TOWN: EXCAVATING ECONOMIC EXPLOITATION THROUGH CANADIAN DOCU-DRAMATURGY
}

\author{
Dr. Aditi H. Vahiya \\ Mr. Nanavati Devang Sanatkumar
}

\begin{abstract}
The figures that $1 \%$ of the richest possessing $44 \%$ of the world's wealth in 2020 ("Facts: Global Inequality") evidently indicates the immediacy of addressing the horrific economic gaps which have been irreversibly disrupting the socioenvironmental balances across the globe and within the national borders. This paper aims to have a broader view of the glocal implications of this scenario with the help of a Canadian documentary experiment, which can be seen as microcosm of the macrorealities.
\end{abstract}

It may be noted that the Canadian confederation was completed when Newfoundland (in the milieu of which the action of Buchans takes place) joined it at last in 1949- which almost coincides with the constitutional re-formation of India. Like the industrially developing India, the economically developed Canada also aspires to follow democratic ideals and all-inclusive policies which can guarantee the protection of the basic rights, needs and dignity of all human beings, irrespective of their socio-economic status.

It would be interesting to see in this paper as to how Buchnas, a Canadian documentary experiment, brings to light the plights of the labor class working in the darkest corners of the mines, and how the exploitative operations of a giant mining company shown in this play stands for the predatory gaze of all the profit-intensive operations that continue to exploit a huge part of humanity as well as the collective natural sources. 
Keywords: Canadian docudrama, Mining Operations, Exploitation of the Economically Marginalized Working Class.

All-inclusive approach to any socio-economic issue constitutes the spirit of democracy, since an economically-balanced society can hope for attaining holistic growth of its individuals and societal progress in a real sense. It is for this reason that happiness of the last man of the society, according to the Gandhiyan philosophy, should count first whenever it sets its goals of progress that navigate its economic priorities.

It can be observed that on one hand, developed economies like Canada or developing ones like India, they claim to encourage humanitarian culture by safeguarding the basic rights of their citizens; whereas on the other hand, as Buchans would suggest here, they encourage profit-oriented market forces which tend to crush financially poor classes materially, physically, socio-culturally and psychologically, who work hard to boost their economies.

In the post 1950s when young Canada was attempting to establish a distinctive national identity, some playwrights and directors utilized documentary theatre as an artistic tool to respond to that collective aspiration. Their extensive research into the Canadian past made them aware about the significance of conducting an impartial scrutiny of their own past.

Buchans: A Mining Town is one of such documentary experiments. This paper is an attempt to study how the uniqueness of this documentary play could be helpful in exploring complex aspects of the economic problematic many ways. In the first place, it is a collective play which invited participation of the audience whose actual problems were unfolded in their presence. For the Indian as well as the Canadian audience, the most interesting aspect of the play is its democratic spirit that has always guided the spirit of the constitutions of both these nations.

Directed by Chris Brooks, Buchans: A Mining Town is a collective docu-drama produced in 1974 by Mummers Troupe of Newfoundland, Canada. Following the 
wave of Canadian regionalism, between 1972 and 1982, Mummer's populist theatre vocalized various kinds of community problems with a view to projecting some of the socio-cultural and economic realities hidden under suppressive economic and socio-cultural power structures.

After putting their best efforts in having access to the history of a region and conducting an in-depth study of its available documentary evidences, Brooks' team has focused upon the issues of suffering and privation faced by a small mining community of Buchans, which had been founded in 1926 in Newfoundland by a mining firm called the American Smelting and Refining Company (ASARCO).

It is interesting to study how effectively the play exposes the ways in which the financially giant multinationals have been able to determine the course of lives of the poor. It displays how economically sound sources could continue to exploit the human and natural resources by shaping the self-perceived narratives of progress.

It is pertinent to note that the study of such plays is an interesting and relevant exercise in the present times wherein the human societies need to ponder over the long-term implications of the political influence of the corporate houses-which is becoming quite palpable at present in all domains of human lives.

Till 1940, as the play records, there was no sign of labor grievances in Buchans. During the depression years it was "wise to take... job in Buchans" for the workless Newfoundlanders, as Lee suggests in the play (76). But after the 40s, when the company procured huge profits on account of the sweat and sacrifices of the miners, their union put forward some demands before the company to improve their working conditions and standard of living. The play depicts how the miners underwent dire economic conditions before, during and after the strikes of 1971 and 1972, and how they received a shock of their lives when it was discovered in 1972 that the stock of minerals was completely depleted in Buchans.

By dramatically excavating the causes/consequences that led to the aforementioned strikes, Brooks' team has been able to expose the ways in which 
the expedient economic policies of the giant multinational companies can bring forth destitution and despondence in lives of their helpless employees.

For the progression of this theme, Brooks' team, being one of the most innovative play groups of the $70 \mathrm{~s}$, utilized those contemporaneous experimental techniques that helped them efface the then existing conventional dramatic prototypes from the Canadian stage. By rejecting the traditionally accepted dictatorship of the director, Brooks team in a way theatrically promoted the Canadian, democratic ideal of multiculturalism. Their process of playmaking itself exemplified this fact.

As Allen Filewood reports in "The Political Dramaturgy of the Mummers' Troupe", the team of Brooks worked together and evolved the entire text and also the performance patterns of the text through democratic consultation with one another and with the people on which the play has been focused. During the creative process, they constantly exchanged their views in the matters regarding the choice of the documentary data, and the use of the same to form a proper documentary montage. These artists' genuine efforts to have an access to the original details about the community support Diana Besai's opinion, who has defined the collective documentary experiments of Canada as "factually based inquiries into the societies they depict" ("Documentary into Drama" 187).

During their research work, the team of Buchans also tried to achieve a complete immersion into the environs of the miners' community of Buchans in various ways. For example, the artists used to wear the uniforms of the miners. They also stayed in the bunk houses, visited the underground areas of the mine, took numerous interviews of the miners individually and in public, invited them in the rehearsals, and also shared with them their responses to the re-enactments of their tales. The artists in this way did their best to perceive the life of the miners from the viewpoints of the miners themselves since basically such collectives are expected "to realise vision of a community rather than appropriate their ideas" as Ann Wilson remarks in his editorial note (CTR 3).

In Buchans, the presence of the original objects such as the mine shaft, scaffolding, picket line signs, or the sounds of whistles and blasts and the songs of 
"Solidarity Forever" serve to augment the documentary authenticity of the play, which was one of the basic aims of the director. Brooks, according to Filewood, wanted to "create a genuine people's history of the community" by emphasizing the authenticity of documentary material in Buchans. ("The Political Dramaturgy" 66)

What is worthy of notice here is that despite Brooks' desire to evoke a genuine reflection of history, he has not failed to remind the audience that they are watching the re-enactment of history, and not history itself. For example, the sounds of the plant whistles are made on a penny whistle and "Like all sound effects in the play it is made in full view of the audience" (Stage direction 73). The Agitprop stage property of Buchans, as it happens in James Reaney's The Donnellys, not only disillusions the audience but it also opens their imaginative possibilities further. For instance, the square-set of the mine shaft an iconographic symbol of the mine atmosphere also turns occasionally into a screen for the silent matinee movies (71) or into mine elevator (81) or into a photo frame (103) or even into a concrete frame of reference for the characters to let them enter their past (90). The red banner with the company's logo is to be considered at last also as a train that brings the police force in Buchans (93).

With the help of such anti-illusory use of the objects, the artists of Buchans have been able to establish what the Epic theatre of Brecht had done earlier. About the Brechtian concepts of theater, P.C.David remarks:

While the theatre of illusion tries to recreate a spurious present by pretending that the events of the play are actually taking place at the time of each performance, the epic theatre is strictly historical and seeks to remind the audience that it is merely getting a report of past events. ("Epic Drama" 92)

In Buchans, anti-naturalism reflects not only in the techniques mentioned above; in fact, it reflects in the entire gamut of the drama. It is clearly exemplified in the narrative strategies of the play, for instance. The unfoldment of the individual 
stories told by the miners follows circular rather than linear patterns. These stories of workers' miseries and their sacrifices have been woven in an episodic structure of the play that gradually form a montage and effectively evoke the intended tragic sense of the labor history.

Both acts of the play begin and end with what Allen, an old miner, calls "dangerous stories". In fact, the entire history of Buchans has been narrated through the Mummer's popular device of storytelling which discloses the histories of individual miners bit by bit. A miner Bembo says that he had come to Buchans just after his wedding, leaving his wife at home. When he returned home after eleven months, he found his wife a complete stranger. "And, I hate to say it," says Bembo, "but I didn't want to make love to her... my own wife... she was a stranger to me." (78).

What enhances the dramatic effects of stories of the miners on account of their long absence from their homes is the well-timed interpolation of story of the same nature introduced by another victim of the same situation.

Bembo's story is immediately followed by the moving narration of another character Donna, who describes how a miner yearns to return to home on Christmas. The perspective of the family members staying in the home town intensifies the thematic focus further. Another story of a miner anxiously worrying about his pregnant wife, living back at home in the same poverty as his in Buchans (76) suggests the kind of anxieties the miners must have gone through in past. Immediately after her account, we have little Allen's recollections. Allen says how he was hardly able to recognize his father; who, being a miner could not stay with his family during the whole year. But on Christmas, when he would come home with play things for Allen, as Allen says, he was "Kinda like Santa Claus to us" rather than a father (78).

The skillfully designed sequence of such stories, while effectively keeps reiterating how the miners suffered emotional wounds, they also successfully project the simultaneous physical injuries borne by the miners. Some of them also suffered lost their ears, legs or even whole bodies due to the unbearable explosions of the 
mine blasts, the accidental discharge of poisonous gases or the occasional landslides as the other stories indicate (87/86).

The first act ends with the sad dismissal of the former activist cum newly promoted miners' leader Mr. Les Forward (96), and the second and final act concludes with Allen's sad words, who started the very first story.

After the depletion of minerals when the strike comes to a tragic end and when miners are shown grouping in a dark of total confusion, engulfed by the black smoke of uncertainties and anxieties of their hopeless and gloomy future, old Allen thus concludes the play: "Well now, we have told you a story. We could have told you a very dangerous story" (114).

Though told by a separate miner, each of these stories follows a curiously spiral but chronological pattern. For example, Lee-Connie Separation Story (76) incorporates past (through the letter reading), present (the re-enactment of the episodes taken up from the couples' life) and it also drags us into further past (through the husband's monologue). The interaction between the past and the present of the dramatic action is another important technique that the team of Buchans has drawn from the dramatic repertoire of the anti-naturalist theatre for effective expose of the real.

While the traditional device of storytelling helps the artists of this collective play in narrating the past in an indirect manner; the simultaneous unfoldment of history through occasional exhibition of the relevant photographs of the specific episodes add scientifically enriched perspectives to the performance.

The photographs in Buchans not only serve to mirror particular geographical locations of Buchans but, like the device of Map shifting used in The Dounellys, they also intensify symbolically the worsening situation of the miners.

In fact, the photographs placed in Buchans are no ordinary photos. As it happens in another Canadian documentary collective called Medicare, in Buchans too the literal photographs are animated to revive the past vividly. In Medicare, A doctors' 
panel is shown coming to life out of a newspaper photograph (202) whereas in Buchans, as soon as Connie declares that the Buchans photo Album is going to be shown, "The actors form the photos in the frame of the square-set:" (Stage direction 103).

The method of re-presenting the past complements Tanya's definition of a documentary experiment. Tanya, a character of Fothergill's Public Lies, making a documentary film herself in the play, says that a documentary play is a "creative interpretation of actuality" (104). The photo album sequence of Buchans also creatively interprets the history of Buchans relating to the years between 1949 and 1955. As the photographs are "enacted" one after another, the characters comment upon the specific events and the locations shown in the photos.

The photos describing "Crowd jammed in tiny space", "moose heard" and the "Stampede of moose" (104-105) have been placed just after the scene in which the darker, narrower bunk houses of the miners were described as nothing better than "Pig Sties" (101); and earlier than that, a ballad recited by the players has already narrated the fact that how the miners, in their desperate attempts to catch the speeding train going home wards before Christmas were injured (99). The audio-visual effects of the ballad and the photo album together augment the fact that the miners were treated in Buchans not better than animals. To suggest the same phenomenon, in another noteworthy Canadian playwright Carol Bolt's docudrama Buffalo Jump also a desperate stampede of workers is shown in the Trek-Train scene (419-420).

In Buchans, the increasing economic imbalance between the company's financial position and that of the miners has been depicted with the help of the screen projectors. In the first act when a voice reports the figures of the company's financial strength, "A backlit figure in silhouette on the sheet grows larger as the profits increase" when the ASARCO theme song taken up from the company's promotional film is heard (75); whereas, in the second act, just before it has been reported that in the decade between 1950 and 1960 the assets of the ASARCO "grew from 350 million dollars to 470 million dollars," the lights dim, and "The actors sing the ASARCO song as shadows loom ever larger on the screen"(105). 
Thus, in both the acts the huge shadows looming large over the tiny figures of the miners symbolically indicate the increasing economic strength of the giant multinational against the economically underdeveloped miners. To ironically suggest that it is the great sacrifices and helplessness of the poor miners that had contributed significantly into the strengthening of the economic soundness of the company immediately after the profits have been reported as mentioned above, what is heard is the news about the tragic deaths of the miners who died of lung diseases they had developed on account of their constant inhaling of the mine dust. "Now we got a guy here," says Howie, "sure he's dyin' and he won't quit. He's full of silicosis, he's dying' by inches and he won't quit... because he's not 64 yet and he won't get a full pension" (105).

It is only after narrating thus the tales of the miners' sacrifices that the director has placed the 25-years-watch-presentation-scene so that Lee's satire upon the company's ludicrous offer of compensation, his appeal for action and the strikes that follow can be justified.

Besides describing the situation of the poverty-stricken miners, Buchans also records the wearisome existence of the women whose lives too are regulated / controlled by the plant whistles. The women gather in one scene and sing: "who says we don't work by the whistle, with us it just don't show/... I'm up at a quarter to six when the alarm clock rings. "Cause he's got to eat and be out the door before that whistle sings. I got to watch the baby, wash the floors and iron the clothes. But you got to have the potatoes on before that whistle blows..." (102). The reiteration of the words "got to" generate aversion towards the perpetual state of enslavement into which the women have been pushed into.

In another scene, Donna's speech "builds to incoherent hysteria," when her incessant verbal blasts generate an intolerable tedium due to her too-precise calculations about the exact size and number of sandwiches, cookies and cakes she has to make every day/week/year (90). Through the songs of the women and through Donna's speech, the artists have been able to effectively elicit sympathy for the Buchans' women folk as well, who have been trapped, along with their men 
folk, into the mechanical, jellified and inevitable routine of suffocative and insensitive industrial milieu of a corporate giant.

Being mummers, Brook's team has also appropriated mime and puppetry to ridicule the nonchalance of the people-who represent the bureaucratic and the law and order systems. The police that enter Buchans are papier machi puppets (93). Magistrate Hollet has also been caricatured (95). Commissioner Woods has been played by Connie who ties her braids to show the moustache of the Commissioner (95). The Arbitration Board which was supposed to consider the miners' complaints remains completely unconcerned exactly like the Canadian PM Mr. Benett of Carol Bolt's Buffalo Jump, who coldly evades the worker's demands in a similar negotiation scene (438-439). In Buchans, the miners' pleas: "we demand" spoken three times are completely ignored by the Arbitration Board (95).

The worker-management-meeting scene in which no actual negotiation takes place is followed by a fantastic piece of mime narrating the sad removal of Les Forward, who had been actually dismissed by the ASARCO for his union activities. While Lee and Howie, being detached observers of the scene, narrate that episode, Bembo plays Les Forward; whereas, Allen plays double roles. While he represents the ASARCO management, he also announces the reenactment of Les Forward Story this way:

ALLEN. The Les Forward Story. (BEMBO stands like a puppet in the frame of the square-set).

LEE. Les forward joins the union and gets his union card. BEMBO. Thank you.

LEE. Les Forward is elected president of that union.

BEMBO. Thank you.

HOWIE. Les Forward is offered a job with the company as mill foreman.

BEMBO. Thank you.

HOWIE. Les Forward passes over his union card.

ALLEN. Foreman do this. (He makes a face. BEMBO copies

it.) 
Foreman do this (Another face). Foreman do this. (Another)

Foreman do this (He waves, BEMBO waves back).

EVERYONE. Bye Les.

(Whistle)

BEMBO. There'll be a ten-minute intermission.... Bye. (96)

It can be anticipated here as to how an effective combination of the traditional art of mime and the Experimental technique of Switch of Roles enables the troupe of Brooks to emphatically suggest how the divisive and deceptive policies of the ASARCO management unnerved a powerful leader and transformed him into a mere puppet. This scene metaphorically affirms how the financially superior corporate power structures always seek to establish the 'Madari-Jambura' relationship between the employer and the employees.

Here, Les Forward bas been compelled by the management to mute the human being staying inside him just as the materialistic Mr. Bernick, a ship builder of Ibsen's Pillars of the Society compels his honest foreman Mr. Aune to carry out an unprincipled assignment of sending a leaky ship into the sea (34). One also remembers how in Sharon Pollock's Walsh also the Major Walsh has been forced by the political power structures to play puppet and execute an unethical dutywhich gnaws the Major from inside.

To satirize the insensitivity of such inhuman, dominant political and economic power systems, here the team of Buchans has skillfully used, as mentioned before, the art of puppetry and mime as Reaney has done in The Donnelleys. Like the Governor General and his lady and the political stooge Mr. Cororan of The Donnelleys, in Buchans also, as mentioned earlier, the Commissioner Mr. Woods, the Magistrate Mr. Hollet, the police party, and the ASARCO management have been either caricatured or shown as puppets. Referring to the Les Forward story, Alan Filewood rightly points out that the enactment of that story is a caustic satire on the process of the dehumanization of the miners. He further adds that in Buchans puppetry "is not simply[a] reductive satire but a theatrical argument that the organs of the society that profit from the dehumanization of the workers are themselves dehumanized" (Political Dramaturgy 66). 
For the further exposure of the exploitative policies of the ASARCO, the team of Collective has incorporated a most significant scene of the twenty-five-year-watchpresentation-scene (106-107). Here, a miner has been allotted a space to purge out his pent-up sense of betrayal and scorn against the company's gambit of offering just a wristwatch to those poor miners who have sacrificed twenty-five years of their lives in the dark corners of the mines, working in dangerous conditions and frequently ending up with silicosis and other diseases.

The scene referred to starts as Mr. Booth, an official of the ASARCO, requests a miner to step up to receive his "Fine Hamilton watch". But "At this point the Actors freeze as the director steps on the stage" (106). Here, the director himself intervenes the dramatic action just as in Medicare!, the character of MLA Thibault steps out of the scene and addresses the audience directly to explain his proMedicare policy (186). In Buchans, Brooks interrupts the scene and begins to explain as to how during the rehearsal of that scene one retired miner who had never attended the twenty-five-year-party "came up form the back of the hall and he walked into our rehearsal and acted it out for us. This is exactly what he said" (106). At this moment, as the freezed actors again come to life and as the scene progresses, Lee, in a style akin to that of the miner Mr. McPhil of Robert Fothergill's Public Lies (109), stands up and in a speech that runs for nearly five minutes straight away reveals the hypocrisy of the economically dominant, thickskinned power structures.

It is pertinent to note that the watch- presentation scene that marks emotional climax of the play is important from various perspectives. For example, Brooks' interruption in the action establishes the fact that this documentary experiment itself is a process of political intervention into the community problems. Secondly, as Filewood remarks, Brook's intervention can be equated with that of the retired miner's in the rehearsal hall, which proves how "an outside element changes the substance and context of an already established structure" (Political Dramaturgy 10). Thirdly, Brooks' method of intimating the audience as to how they came across the documents and how this play has accommodated the real speech of a miner authenticate his dramatic version of Buchan's history. 
Moreover, this scene also augments the fact that in spite of the appropriation of Agit-prop theatricalism and its corresponding themes, the play does not take sides with Marxist theories. According to Filewood, in a conservative society of New Foundland Marxist ideals would have distracted the audience away from Brooks' theatre. But that did not happen since Brooks' team has studied the history in a disinterested manner. In this watch presentation scene, Lee admits that he does not want to "criticize or ridicule" the company. He says he only wants to argue that the ASARCO "never gave me anything I never worked for". He logically insists that against the cost of physical and emotional sacrifices and the steady, dedicated service of twenty five years of the miners, what the company offers as a token of compensation seems to be an insult to the miners' community (107).

Filewood truly opines that "Buchans is pro-union but it is not anti-capitalist... It accuses the company of irresponsible profiteering and criticizes it for depriving the townspeople of basic rights and dignity" (Political Dramaturgy 69).

The Watch-Presentation-Scene while it proves that Buchans is an impartial artistic statement upon the labor history of Buchans, it also implies that such carefully researched documentary works can do something more for a community besides providing entertainment. By offering enough space to the protagonist [a retired miner] for the purgation of his pent-up grievances, Buchans establishes the social relevance of such documentary experiments.

Talking about the functional values of docudramas, Lena De Guevara quotes an experience of a Labanese woman who, at the end of the last rehearsal of a Collective docudrama called Sisters and Strangers, came up and acknowledged with tears that she felt healthy again because it was the theatre that relieved her of her previous inhibitions and sense of dispossession that she gathered on account of the destruction of her homes she witnessed several times during the sixteen years of war. Referring to the Lebanese women's experience, which is analogous to the miner's as documented in Buchans, Guevara writes: "It has renewed my belief in the ethical, healing and transformative powers of theatre" (31. Sisters/ Strangers). 
Towards Excellence: An Indexed, Refereed \& Peer Reviewed Journal of Higher Education / Dr. Aditi Vahiya \& Mr. Devang Nanavati/ Page 1-16

As Guevara has suggested, the study of Buchans also, besides recognizing the importance of the functional aspects of the form of the documentary drama, it can be concluded that it is the dexterous manipulations of the technical aspects of the documentary dramaturgy with which, as it has been discussed, the team of Brookes has been able to effectively re-present and re-define the pre-established Canadian cultural myths by successfully documenting the 'real' socio-politicoeconomic Canadian past. 
Towards Excellence: An Indexed, Refereed \& Peer Reviewed Journal of Higher Education /

Dr. Aditi Vahiya \& Mr. Devang Nanavati/ Page 1-16

\section{Works Cited}

Bessai, Diane. "Documentary into Drama: Reaney's Donnelly Trilogy." Essays on Canadian Writing: James Reaney Issue. 24-25. (Winter-Spring/ 1982-83): 186-206.

Bolt, Carol. Buffalo Jump. Perkyns, Major Plays. 384-442.

Brookes, Chris. Directed by Buchans: A Mining Town. Canadian Drama / L'Art dramatique.13. (Nov./Numero, 1, 1987): 72-115.

Coulter, John. "Riel." Perkyns 125-210.

David, P.C. "Epic Drama: From Brecht to Bond." Critical Practice 2.2 (June 1999): 91-96.

De Guevara, Lina. "Sisters/Strangers - A Community Play about Immigrant Women." CTR 90 (Spring 1997): 28-31.

Deverell, Rex. Medicare! As a one man Collective. Bessai and Kerr.184-259.

"Facts: Global Inequality." Edited by Sarah Anderson, Inequality.org, 16 Feb 2020, inequality.org/facts/global-inequality/. Accessed 28 Feb 2020.

Filewood, Alan. "The Political Dramaturgy of the Mummers Troupe." Canadian

Drama/L'Art dramatique Canadian 13.1 (1987): 60-72.

Fothergill, Robert. Public Lies. CTR 79/80 (Summer/Fall) 1994: 86-115.

Ibsen, Henrick. The Pillars of Society. Madras: MacMillan, 1986.

"Facts: Global Inequality." Edited by Sarah Anderson, Inequality.org, 16 Feb 2020 ,

inequality.org/facts/global-inequality/. Accessed 28 Feb 2020.

Vancouver: Talon Books, 1993. 237-371.

Reaney, James. The Donnellys. Victoria: Press Porcepic, 1983.

Wilson, Ann. Editorial. CTR 90 (Spring 1997): 3-4.

\section{Dr. Aditi H. Vahiya \\ Assistant Professor \\ Department of English \\ Faculty of Arts \\ Maharaja Sayajirao University of Baroda, Vadodara \\ Email: aditivahia@yahoo.com}


Towards Excellence: An Indexed, Refereed \& Peer Reviewed Journal of Higher Education / Dr. Aditi Vahiya \& Mr. Devang Nanavati/ Page 1-16

\&

Mr. Nanavati Devang Sanatkumar

Associate Professor in English

SKUB Samiti Arts \& Smt. N. C.Zaveri Commerce College, Pipaliya Email: nanavati68@gmail.com 